\title{
ELEMENTS OF THEORY OF THE CORRECT OPERATIONS OF LOGISTICS TRANSFORMING NETWORKS
}

\author{
Tadeusz KRUPA \\ Warsaw University of Technology, Faculty of Management, Warsaw, Poland \\ e-mail: tadeusz.krupa@pw.edu.pl
}

\begin{abstract}
In this paper, transformer logistics networks are treated as flow models of discrete manufacturing systems (FMDMS). The purpose is to formalize FMDMS into logical formulas called transformer functions. Transformer logistics networks are able to handle buffers and their production orders in a way that ensures full monitoring of the logic technology stored in the memory of a transforming network (t-network). The structural and functional complexity of the t-network makes it impossible to carry out formal proof of its proper functioning for any new order placement in buffers and transformers. This is because with the growing capacity in buffers, the number of available states of tnetworks also increases, and as such, the number of transformers and buffers unable to effectively generate new production orders that protect the t-network is also increasing. The problem therefore becomes to maintain t-network equilibrium technology that guarantees the continuity of the logical operations and processes of resource transformation.
\end{abstract}

Keywords: buffer, logic algebra functions, product, alternative concentric and scattering transformers, parallel concentric and scattering transformers, technological process, technological equilibrium, resource, production order.

\section{Introduction}

Reflections on the essence of transforming networks (t-networks) start from the concept of a t-network the characteristics of which were first developed and presented at the International Conference SYPRO' 90 in Warsaw, and then in a series of other works (Krupa, 2000, 2002, 2010). In this article, the author's attention is focused:

- on the monitoring of logical operations of key importance for their synchronization and feasibility in various phases of technological processes; for methodological reasons, processing objects are abstract orders (representing production tasks) executed on resources without detailed resource characteristics,

- on the logical modeling of technological operations in the simplified language of the algebra of logic functions ${ }^{1}$ so that they imitate the basic technological operations of assembly and disassembly, technological operations of shaping the form of resources through the selection of the de- sired properties of their characteristics, as well as storage and transport operations,

- and on the issue of the multitasking of the network in terms of its proper functioning with respect to the determinants guaranteeing execution of the order flow directed towards the implementation of its input, transmission and output cooperation buffers.

\section{Construction and operation of the transforming network}

The t-network is constructed on the basis of experience gathered during experiments performed on the flow models of production systems (Ostrowska, Krupa, 2014, 2017) and on experience from colored Petri nets simulations (Krupa, 2002). It seems to eliminate ambiguity met in event modeling performed with marker flow through positions and transitions in Petri nets. The possibility of applying many practical constraints to its structure is one of the essential t-network advantages.

\footnotetext{
${ }^{1}$ So-called Boolean functions.
} 

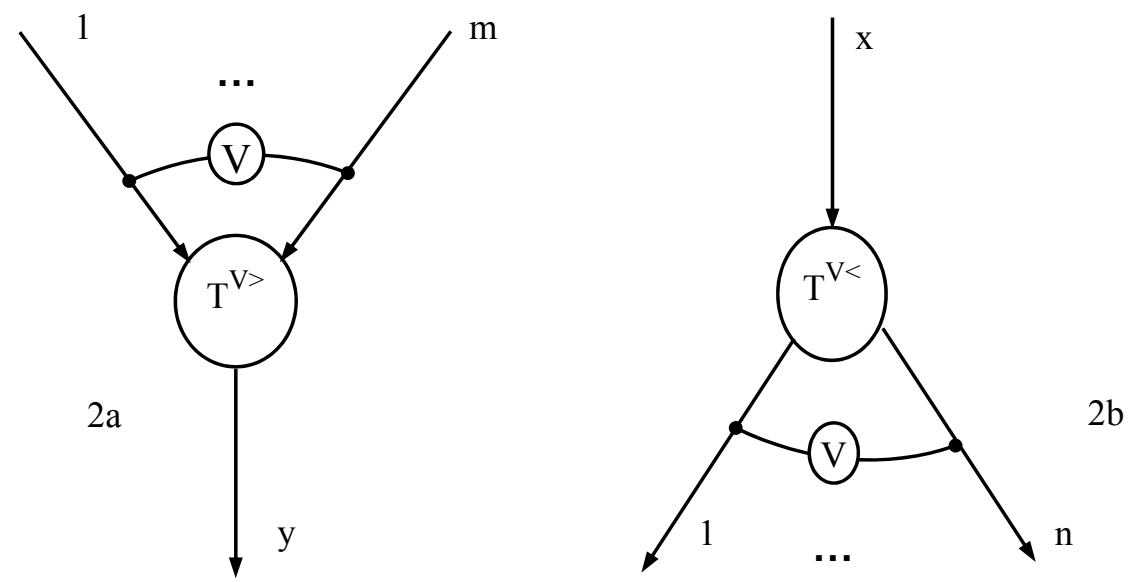

Figures $2 \mathrm{a}, 2 \mathrm{~b}$. A transformer $\mathrm{T}^{\mathrm{V}>}$ that concenters alternatively and a transformer $\mathrm{T}^{\mathrm{V}<}$ that scatters alternatively $\mathrm{T}^{\mathrm{V}<}$ (source: own elaboration)
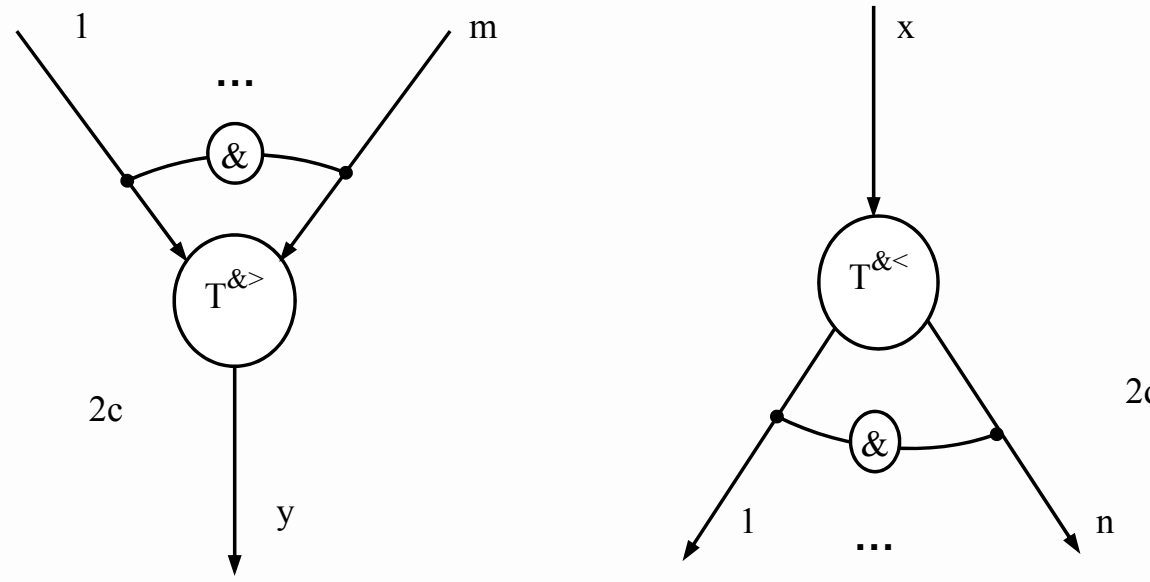

Figures $2 \mathrm{c}, 2 \mathrm{~d}$. A transformer $\mathrm{T}^{\&>}$ that concenters parallelly and a transformer $\mathrm{T}^{\&<}$ that scatters parallelly (source: own elaboration)

T-network directly refers to the concept of scheme operating tasks (SOT) ${ }^{2}$.

In classical SOTs, this is represented by a network of partial tasks, implemented in parallel block diagrams (PBDs) ${ }^{3}$, linked by alternating and parallel links (concentrating and scattering). Likewise, theoretical models of the t-network also occur.

\footnotetext{
${ }^{2}$ Operational schema of a task (OST) - a structure in which the tasks performed are uniquely linked to their order, alternation, concurrency and cyclicality

${ }^{3}$ Block synchronous scheme (BSS) - a schema constructed from operational boxes performing transformational tasks (e.g., arithmetic or technological) and from logical boxes performing two or n-valued functions of the predicate domain attributed to its arithmetic or technological counterparts.
}

In the case of the t-network, we have to deal with the flow of orders between buffers which are accompanied by a change in the conditions of production resources and associated logic models of technological operations.

Orders and resources are represented in the $\mathrm{t}$ network by ordering production tasks, while the task execution process is monitored (modeled) by the order flow through the $\mathrm{B}^{\mathrm{X}}$ production buffers and logic operations of the logic algebra functions (LAF) performed on these jobs by the t- network.

The basic elements of the construction of t-networks are:

- Alternative concentering and scattering transformers (Fig. 2a, 2b) parallel concentric and scat- 
tering transformers (Fig. 2c, 2d), which, on the basis of orders, execute structured and functional order processing procedures. The result of logical operations on orders is a change in the structure of resources consisting of their fragmentation or focusing on a uniform form in the receiving buffers.

- Production buffers (or $\mathrm{B}^{\mathrm{X}}$ production orders in memory buffers) that store collections of orders for $\mathrm{X}$ representing products and their variants (e.g., a, b,... j) already made or for products to be made. Product orders are stored in supply, transmission and receiving buffers (see Fig. 2e,
$2 \mathrm{f}, 2 \mathrm{~g}$ ) in the form of orders describing the input and output products, defining the number of products and their priority indicating the priority of the production order $\mathrm{X}$ of the product in the transformer serving the given buffer from the $\mathrm{B}^{\mathrm{X}}$ buffer feed side or from the order picker $\mathrm{X}$ side of the $\mathrm{B}^{\mathrm{X}}$ buffer.

A properly constructed t-network should have at least one supplier buffer, $\mathrm{B}^{\mathrm{S}}$ (Fig. 2e), a necessary number of transmission buffers, $B^{\mathrm{T}}$ (Fig. 2f), and at least one receiver buffer, $\mathrm{B}^{\mathrm{R}}$ (Fig. 2g), connected to transformers.

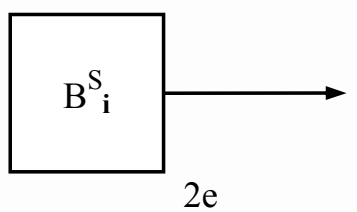

$2 \mathrm{e}$

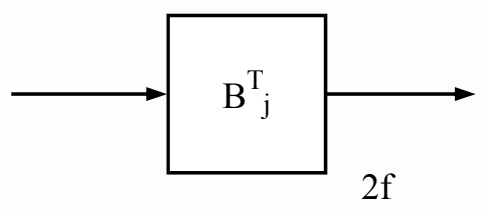

$2 \mathrm{f}$

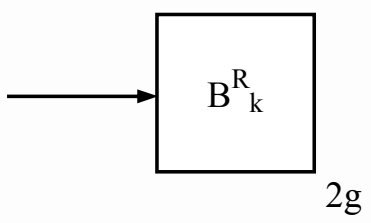

Figures $2 e, 2 f, 2 g$. Buffers: $\mathrm{B}^{\mathrm{S}} i$ supplier, $\mathrm{B}^{\mathrm{T}} \mathrm{j}$ transmitter, and $\mathrm{B}^{\mathrm{R}} \mathrm{k}$ receiver (source: own elaboration)

Transformers perform their logical operations on orders received from supplying, transmission or receiver buffers. The requirement for a technology operation is the availability in the supply buffers (Fig. 2e) of orders made in sufficient quantity to execute orders in transmission or receiver buffers.

It is important to remember the different behavior of the 4 types of transformers:

- alternative concentering,

- alternative scattering,

- parallel concentering,

- and parallel scattering.

If an alternate combination of the starting process operations of the transformer alternative (focusing or diffusing) cannot be completed (no space in the receiver buffer) - the order of the transformer without change returned to the input buffers - it means that the transformer alternative has not been used to implement any order assigned to it by the t-network operating system.

If no parallel (simultaneous) combination of output operations of a given parallel transformer (concentrating or scattering) can to be realized (no space in the receiver buffers) - the transformer's orders are unal- tered back to the input buffers - it means that the parallel transformer has failed any order assigned to it by the t-network operating system.

The above two key determinants of the t-network performance will be presented in the examples of the transformer network shown in Fig. 3a. Due to the necessity of ensuring efficient processes of order transformation in the t-network, it is necessary to monitor all operations concerning orders, production buffers and logical transforming functions characterizing each of the transformers.

\section{Determinants of monitoring technological operations in the transforming networks}

Fig. 3a shows an example of a zero state of tnetwork constructed with 10 production buffers: $\mathrm{B}_{1} \ldots \mathrm{B}_{10}$ and 6 logic transformers: $\mathrm{T}_{\mathrm{I}}^{\&<}, \mathrm{T}_{2}^{\mathrm{V}>}, \mathrm{T}_{3}^{\mathrm{V}<}$, $\mathrm{T}_{4}{ }^{\mathrm{V}<}, \mathrm{T}_{5}{ }^{\mathrm{V}>}, \mathrm{T}_{6}{ }^{\&>}$. Transformers are not capable of performing any alternate and concurrent logical expressions since all the production orders stored in the buffers (Fig. 3a) have an initial value of 0 (the buffers at the beginning of the simulation experiment do not contain any production orders; they are simply empty). 


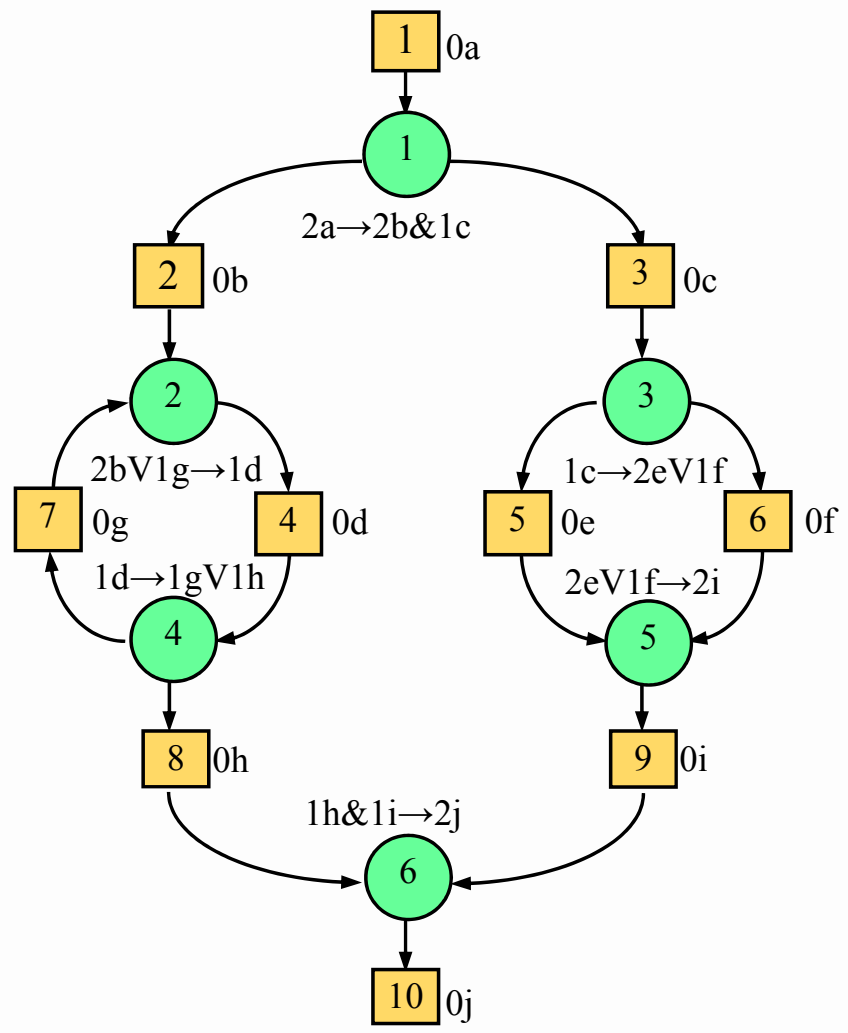

Figure 3a. Example of t-network with feedback (source: own elaboration)

Table 3a. An example of a functional model of a logical transformers t-network

\begin{tabular}{|c|c|c|c|c|}
\hline & transformers & $\begin{array}{l}\text { processes of input } \\
\text { products }\end{array}$ & $\begin{array}{l}\text { power supply } \\
\text { product order } \\
\text { technologies }\end{array}$ & $\begin{array}{c}\text { one-sided alternative trans- } \\
\text { formations } \mathrm{V} \\
\text { and conjugate \& }\end{array}$ \\
\hline 1 & $\mathrm{~T}_{\mathrm{I}}^{\&<}$ & $2 \mathrm{a}$ & $2 b \& 1 c$ & $2 a \rightarrow 2 b \& 1 c$ \\
\hline 2 & $\mathrm{~T}_{2}^{\mathrm{V}>}$ & $2 \mathrm{~b} \mathrm{~V} 1 \mathrm{~g}$ & $1 \mathrm{~d}$ & $2 \mathrm{~b} \mathrm{~V} 1 \mathrm{~g} \rightarrow 1 \mathrm{~d}$ \\
\hline 3 & $\mathrm{~T}_{3}^{\mathrm{V}<}$ & $1 \mathrm{c}$ & 2e V 1f & $1 \mathrm{c} \rightarrow 2 \mathrm{e} V 1 \mathrm{f}$ \\
\hline 4 & $\mathrm{~T}_{4}^{\mathrm{V}<}$ & $1 \mathrm{~d}$ & $1 \mathrm{~g} \mathrm{~V} \mathrm{1h}$ & $1 \mathrm{~d} \rightarrow 1 \mathrm{~g} \mathrm{~V} 1 \mathrm{~h}$ \\
\hline 5 & $\mathrm{~T}_{5}^{\mathrm{V}>}$ & $2 \mathrm{eV} 1 \mathrm{f}$ & $2 \mathrm{i}$ & $2 \mathrm{e} V 1 \mathrm{f} \rightarrow 2 \mathrm{i}$ \\
\hline 6 & $\mathrm{~T}_{6}^{\&>}$ & $1 \mathrm{~h} \& 1 \mathrm{i}$ & $2 \mathrm{j}$ & $1 \mathrm{~h} \& 1 \mathrm{i} \rightarrow 2 \mathrm{j}$ \\
\hline
\end{tabular}

The presented t-network includes different types of elements:

- transformers:

- alternative concentering transformers $\mathrm{T}^{\mathrm{V}>}$ (Fig. 2a),

- alternative scattering transformers $\mathrm{T}^{\mathrm{V}<}$ (Fig. 2b),

- parallel concentering transformers $\mathrm{T}^{\&>}$ (Fig. 2c)
- and parallel scattering transformers $\mathrm{T}^{\&<}$ (Fig. 2d),

- transformers cannot be directly connected to each other. An alternative transformer concentering $\mathrm{T}^{\mathrm{V}>}$ can have multiple inputs and one output; an alternative transformer scattering $\mathrm{T}^{\mathrm{V}<}$ can only have one input and one multiple outputs,

- a single input and one output transformer is called a transmission transformer and is designated $\mathrm{T}^{=}$, 
- transformers, for the purpose of controlling the processing of resources, have a collection of alternative technological orders and run according to their priorities for the execution of these orders,

- buffers cannot to be directly connected to each other,

- buffers have a priori defined maximum storage capacity stored technology - in addition to each buffer, there may be associated indicators set to minimal and optimal order fulfillment to protect the continuity of the network's operation which can be measured by the total waiting time of transformers for successive orders,

- appropriate strategies for initiating transformations of orders and their distribution in buffers of t-nets,

- channels alternately connecting transformers and buffers,

- logical functions describing alternative - convergent processing of orders in transformers;
- priorities determining the order of processing orders from the production order buffers (in this example the priority of the buffer selection is marked with "*"),

- a t-network system operating the production orders targeted to $\mathrm{B}^{\mathrm{X}}$ buffers. The task of the $\mathrm{t}$ network operating system is to maintain it in a state of technological equilibrium, guaranteeing optimum use of production orders, the working time of the logic transformers, and the buffer capacity of the production orders $\mathrm{B}^{\mathrm{X}}$.

Fig. 3a1 shows an example of the initial state of the t-network performing concurrent and cyclic technological processes on orders stored in its 10 buffers: $\mathrm{B}^{1}=3 \mathrm{a}, \mathrm{B}^{2}=0 \mathrm{~b}, \mathrm{~B}^{3}=1 \mathrm{c}, \mathrm{B}^{4}=1 \mathrm{~d}, \mathrm{~B}^{5}=1 \mathrm{e}, \mathrm{B}^{6}=1 \mathrm{f}$, $\mathrm{B}^{7}=0 \mathrm{~g}, \mathrm{~B}^{8}=0 \mathrm{~h}, \mathrm{~B}^{9}=0 \mathrm{i}, \mathrm{B}^{10}=0 \mathrm{j}$. Resource processing is achieved by means of distributed and centralized logic transformers. Monitoring, transformation and displacement of orders are recorded in Table $3 \mathrm{~b} 1$ technology states t-network.

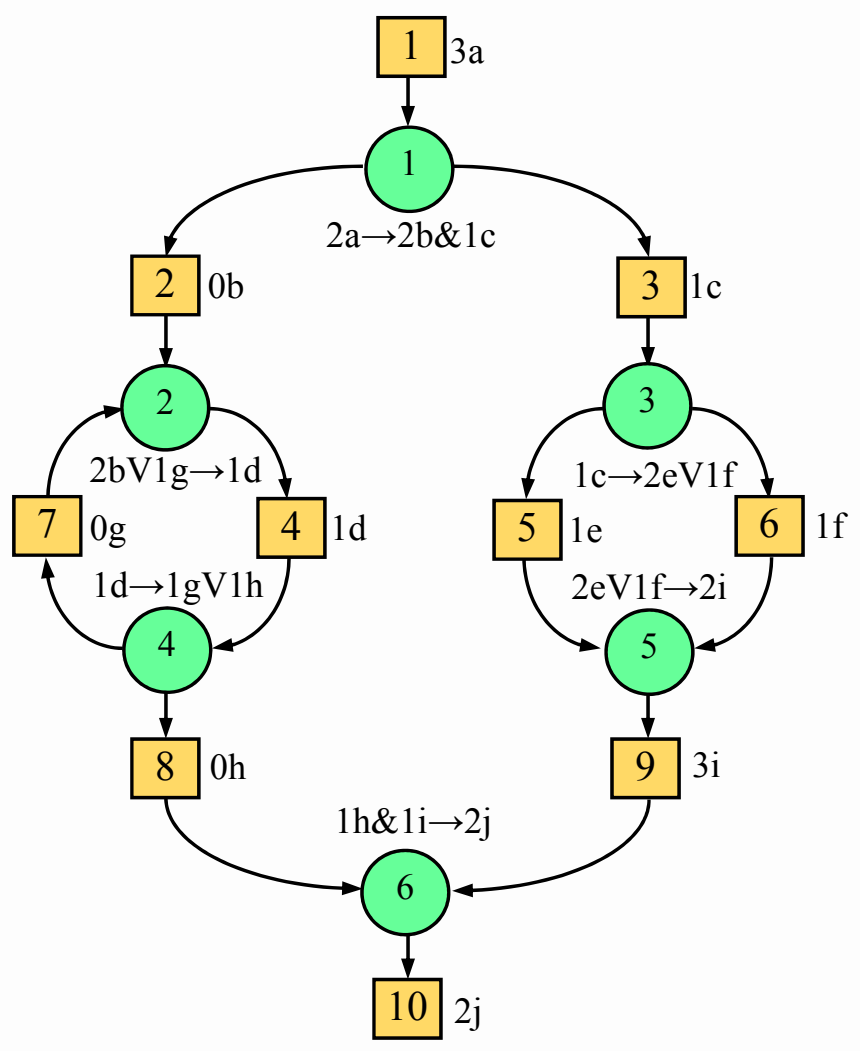

Figure 3a1. The initial state of the t-network implementing concurrent and cyclical processes on the orders stored in the 10 buffers; the t-network state in Fig. 3a1 corresponds to phase 1 stored in Table 3b1 (Group I)

(source: own elaboration) 
Table 3b1. Table of technological t-network states (Group I) - Fig. 3a1

\begin{tabular}{|c|c|c|c|c|c|c|c|c|c|c|c|}
\hline 1 & 2 & 3 & 4 & 5 & 6 & 7 & 8 & 9 & 10 & $\leftarrow$ BUFFER NUMBERS & $\begin{array}{c}\text { Phase } \\
\downarrow\end{array}$ \\
\hline $\mathrm{a}$ & $\mathrm{b}$ & $\mathrm{c}$ & $\mathrm{d}$ & $\mathrm{e}$ & $\mathrm{f}$ & $\mathrm{g}$ & $\mathrm{h}$ & $\mathrm{i}$ & $\mathrm{j}$ & $\leftarrow$ PRODUCT ORDERS & 1 \\
\hline 3 & 0 & 1 & 1 & 1 & 1 & 0 & 0 & 3 & 2 & $\begin{array}{c}\text { initial number of orders } \\
\text { at transformer input }\end{array}$ & $\begin{array}{c}\text { available transformers } \\
\text { in the transformation phase }\end{array}$ \\
\hline 1 & - & 3 & 4 & - & 5 & - & - & - & - & $\begin{array}{c}\text { the current number of orders } \\
\text { at transformer input } \\
\text { in the transformation phase }\end{array}$ & 3 \\
\hline & 0 & 0 & 0 & 1 & 0 & 0 & 0 & 3 & 2 & $\begin{array}{c}\text { number of orders generated } \\
\text { by the available transformers } \\
\text { during the transformation phase }\end{array}$ & 4 \\
\hline
\end{tabular}

In step 4 (yellow background) in the buffers indicated in sequence numbers $2,3,5-9$, there appears in the following order $2 \mathrm{~b}, 1 \mathrm{c}, 2 \mathrm{e}, 1 \mathrm{~h}$ and $2 \mathrm{i}$ generated by the transformers $1,3,4$ and 5 .

Fig. $3 \mathrm{a} 2$ shows an example of the initial state of the t-network performing concurrent and cyclic technological processes on orders stored in its 10 buffers:
$\mathrm{B}^{1}=1 \mathrm{a}, \mathrm{B}^{2}=2 \mathrm{~b}, \mathrm{~B}^{3}=1 \mathrm{c}, \mathrm{B}^{4}=0 \mathrm{~d}, \mathrm{~B}^{5}=3 \mathrm{e}, \mathrm{B}^{6}=0 \mathrm{f}$, $B^{7}=0 g, B^{8}=1 h, B^{9}=5 i, B^{10}=2 j$. Resource processing is achieved by means of distributed and centralized logic transformers. Monitoring, transformation and displacement of orders are recorded in Table $3 \mathrm{~b} 2$ technology states t-network.

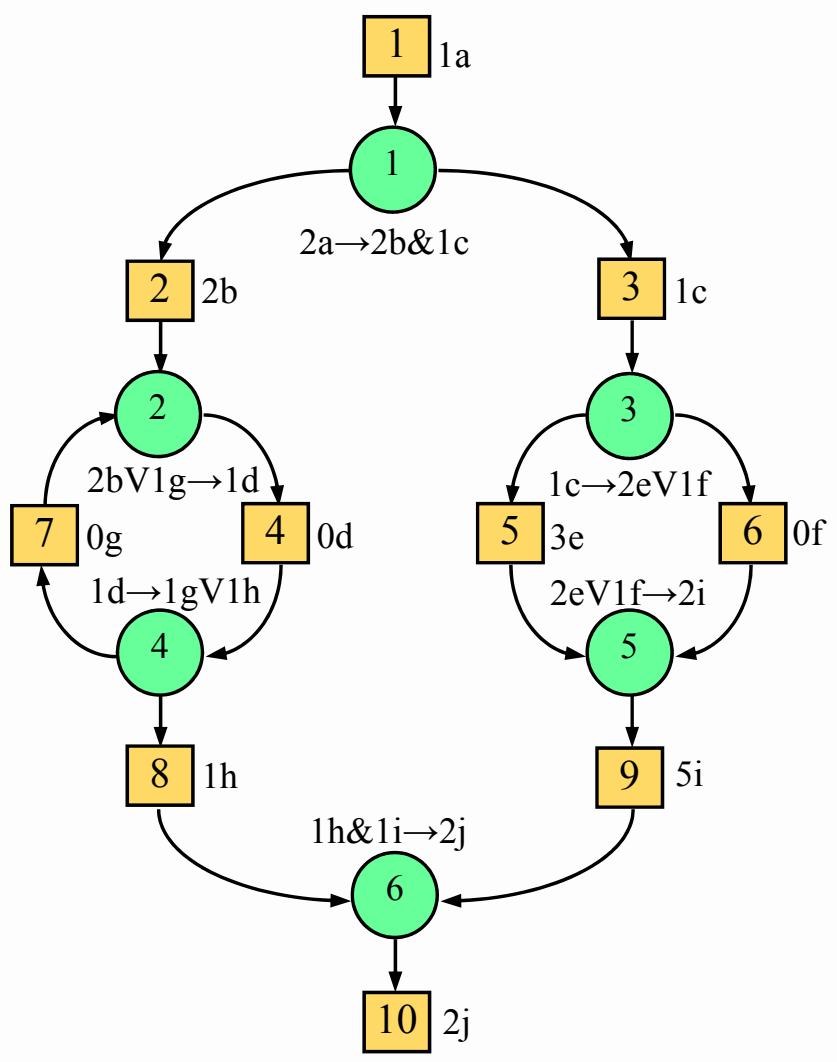

Figure 3a2. The initial state of the t-network implementing concurrent and cyclical processes on the orders stored in the 10 buffers; the t-network state in Fig. $3 \mathrm{a} 2$ corresponds to phase 5 stored in Table $3 \mathrm{~b} 2$ (Group II) 
Table 3b2. Table of technological t-network states (Group II) - Fig. 3a2

\begin{tabular}{|c|c|c|c|c|c|c|c|c|c|c|c|}
\hline 1 & 2 & 3 & 4 & 5 & 6 & 7 & 8 & 9 & 10 & $\leftarrow$ BUFFER NUMBERS & $\begin{array}{c}\text { Phase } \\
\downarrow\end{array}$ \\
\hline $\mathrm{a}$ & $\mathrm{b}$ & $\mathrm{c}$ & $\mathrm{d}$ & $\mathrm{e}$ & $\mathrm{f}$ & $\mathrm{g}$ & $\mathrm{h}$ & $\mathrm{i}$ & $\mathrm{j}$ & $\leftarrow$ PRODUCT ORDERS & 5 \\
\hline 1 & 2 & 1 & 0 & 3 & 0 & 0 & 1 & 5 & 2 & $\begin{array}{c}\text { initial number of orders } \\
\text { at transformer input }\end{array}$ & 6 \\
\hline- & 2 & 3 & - & 5 & - & - & 6 & 6 & - & $\begin{array}{c}\text { available transformers } \\
\text { in the transformation phase }\end{array}$ & 7 \\
\hline 1 & 0 & 0 & 0 & 1 & 0 & 0 & 0 & 4 & 2 & $\begin{array}{c}\text { the current number of orders } \\
\text { at transformer input } \\
\text { in the transformation phase }\end{array}$ & 8 \\
\hline- & - & - & $1^{2}$ & $0^{3}$ & $1^{3 *}$ & - & - & $2^{5}$ & $2^{6}$ & $\begin{array}{c}\text { number of orders generated } \\
\text { by the available transformers } \\
\text { during the transformation phase }\end{array}$ & 8 \\
\hline
\end{tabular}

In step 8 (yellow background) in the buffers indicated in sequence numbers $4,6,9,10$ there appears in the following order $1 \mathrm{~d}, 1 \mathrm{f}, 2 \mathrm{i}$ and $2 \mathrm{j}$ generated by the transformers 2, 3, 5 and 6 .

Fig. $3 \mathrm{a} 3$ shows an example of the initial state of the t-network performing concurrent and cyclic technological processes on orders stored in its 10 buffers:
$\mathrm{B}^{1}=1 \mathrm{a}, \mathrm{B}^{2}=0 \mathrm{~b}, \mathrm{~B}^{3}=0 \mathrm{c}, \mathrm{B}^{4}=1 \mathrm{~d}, \mathrm{~B}^{5}=1 \mathrm{e}, \mathrm{B}^{6}=1 \mathrm{f}$, $B^{7}=0 g, B^{8}=0 h, B^{9}=6 i, B^{10}=4 j$.

Resource processing is achieved by means of distributed and centralized logic transformers. Monitoring, transformation and displacement of orders are recorded in Table $3 \mathrm{~b} 3$ technology states t-network.

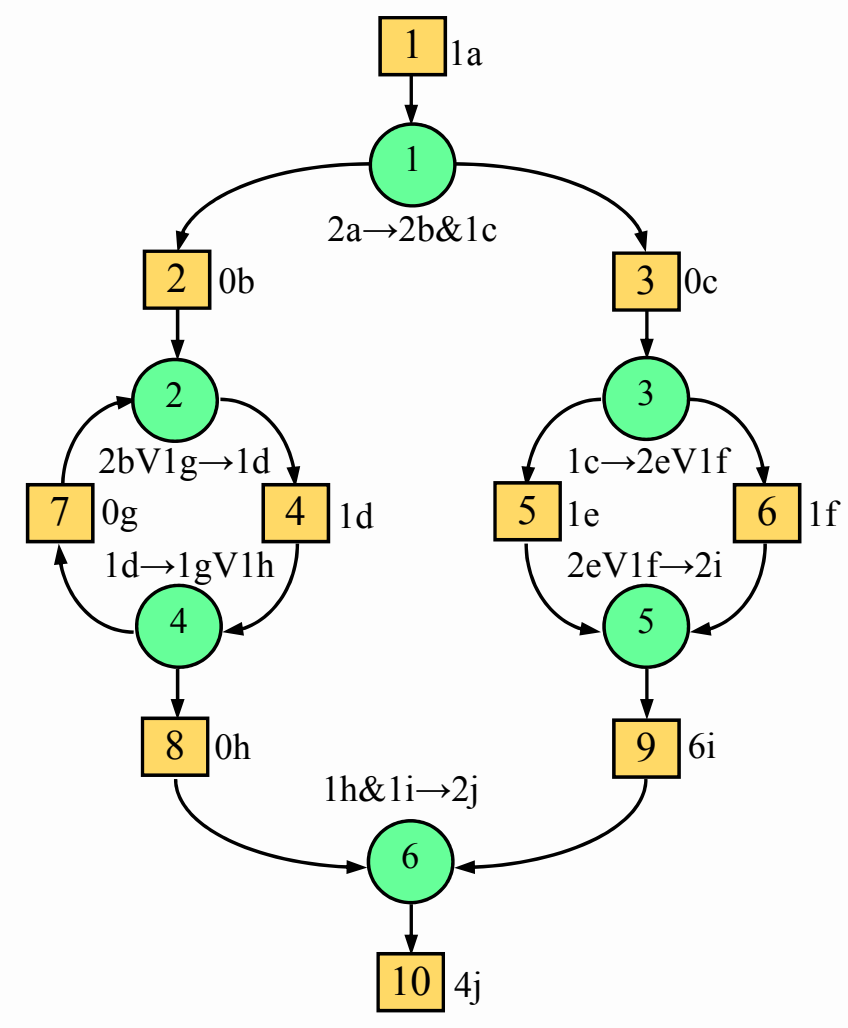

Figure 3a3. The initial state of the t-network implementing concurrent and cyclical processes on the orders stored in the 10 buffers; the t-network state in Fig. $3 a 3$ corresponds to phase 9 stored in Table $3 b 3$ (Group III) 
Table 3b3. Table of technological t-network states (Group III) - Fig. 3a3

\begin{tabular}{|c|c|c|c|c|c|c|c|c|c|c|c|}
\hline 1 & 2 & 3 & 4 & 5 & 6 & 7 & 8 & 9 & 10 & $\leftarrow$ BUFFER NUMBERS & $\begin{array}{c}\text { Phase } \\
\downarrow\end{array}$ \\
\hline $\mathrm{a}$ & $\mathrm{b}$ & $\mathrm{c}$ & $\mathrm{d}$ & $\mathrm{e}$ & $\mathrm{f}$ & $\mathrm{g}$ & $\mathrm{h}$ & $\mathrm{i}$ & $\mathrm{j}$ & $\leftarrow$ PRODUCT ORDERS & 9 \\
\hline 1 & 0 & 0 & 1 & 1 & 1 & 0 & 0 & 6 & 4 & $\begin{array}{c}\text { initial number of orders } \\
\text { at transformer input }\end{array}$ & $\begin{array}{c}\text { available transformers } \\
\text { in the transformation phase }\end{array}$ \\
\hline 1 & 0 & 0 & 0 & 1 & 0 & 0 & 0 & 3 & 2 & $\begin{array}{c}\text { the current number of orders } \\
\text { at transformer input } \\
\text { in the transformation phase }\end{array}$ & 11 \\
\hline- & - & - & - & - & - & $0^{4}$ & $1^{4 *}$ & $2^{5}$ & - & $\begin{array}{c}\text { number of orders generated } \\
\text { by the available transformers } \\
\text { during the transformation phase }\end{array}$ & 12 \\
\hline
\end{tabular}

In step 12 (yellow background) in the buffers indicated in sequence numbers 8 and 9 there appears in the following order $1 \mathrm{~h}, 2 \mathrm{i}$ generated by the transformers 4 and 5 .

Fig. $3 \mathrm{a} 4$ shows an example of the initial state of the t-network performing concurrent and cyclic technological processes on orders stored in its 10 buffers:
$\mathrm{B}^{1}=1 \mathrm{a}, \mathrm{B}^{2}=0 \mathrm{~b}, \mathrm{~B}^{3}=0 \mathrm{c}, \mathrm{B}^{4}=0 \mathrm{~d}, \mathrm{~B}^{5}=1 \mathrm{e}, \mathrm{B}^{6}=0 \mathrm{f}$, $\mathrm{B}^{7}=0 \mathrm{~g}, \mathrm{~B}^{8}=0 \mathrm{~h}, \mathrm{~B}^{9}=0 \mathrm{i}, \mathrm{B}^{10}=0 \mathrm{j}$. Resource processing is achieved by means of distributed and centralized logic transformers. Monitoring, transformation and displacement of orders are recorded in Table 3b4 technology states t-network.

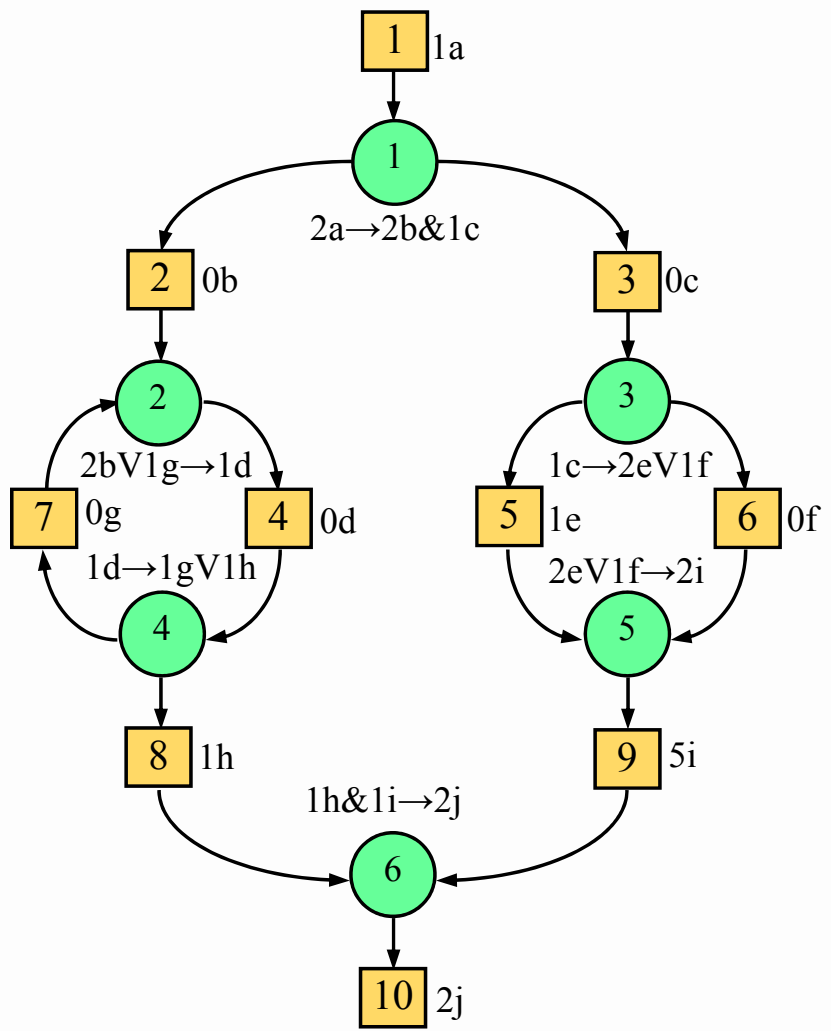

Figure 3a4. The initial state of the t-network implementing concurrent and cyclical processes on the orders stored in the 10 buffers; the t-network state in Fig. $3 a 4$ corresponds to phase 12 stored in the Table $3 b 4$ (Group IV) (source: own elaboration) 
Table 3b4. Table of technological t-network states (Group III) - Fig. 3a4

\begin{tabular}{|c|c|c|c|c|c|c|c|c|c|c|c|}
\hline 1 & 2 & 3 & 4 & 5 & 6 & 7 & 8 & 9 & 10 & $\leftarrow$ BUFFER NUMBERS & \multirow{2}{*}{$\begin{array}{c}\text { Phase } \\
\quad \downarrow\end{array}$} \\
\hline $\mathrm{a}$ & $\mathrm{b}$ & $\mathrm{c}$ & $\mathrm{d}$ & $\mathrm{e}$ & $\mathrm{f}$ & $\mathrm{g}$ & $\mathrm{h}$ & $\mathrm{i}$ & $\mathrm{j}$ & $\leftarrow$ PRODUCT ORDERS & \\
\hline 1 & 0 & 0 & 0 & 1 & 0 & 0 & 1 & 5 & 2 & $\begin{array}{l}\text { initial number of orders } \\
\text { at transformer input }\end{array}$ & 13 \\
\hline- & - & - & - & - & - & - & 6 & 6 & - & $\begin{array}{l}\text { available transformers } \\
\text { in the transformation phase }\end{array}$ & 14 \\
\hline 1 & 0 & 0 & 0 & 1 & 0 & 0 & 0 & 4 & 2 & $\begin{array}{l}\text { the current number of orders } \\
\text { at transformer input } \\
\text { in the transformation phase }\end{array}$ & 15 \\
\hline- & - & - & - & - & - & - & - & - & $2^{6}$ & $\begin{array}{c}\text { number of orders generated } \\
\text { by the available transformers } \\
\text { during the transformation phase }\end{array}$ & 16 \\
\hline
\end{tabular}

In step 16 (yellow background) in the buffer indicated in sequence number 10 there appears only one order $2 \mathrm{j}$ generated by the transformer 6 .

It is worth noting that with each successive cycle (group), the number of transformers available decreases, thus meaning the closure of the production process and the need for preventive action.
4 Products, product variants and production orders in the t-network model

A production order is formulated if it specifies:

- the type of product produced (stock),

- number of repetitions (realization) of the variation,

the time after which the order should be completed from the time it was commissioned.
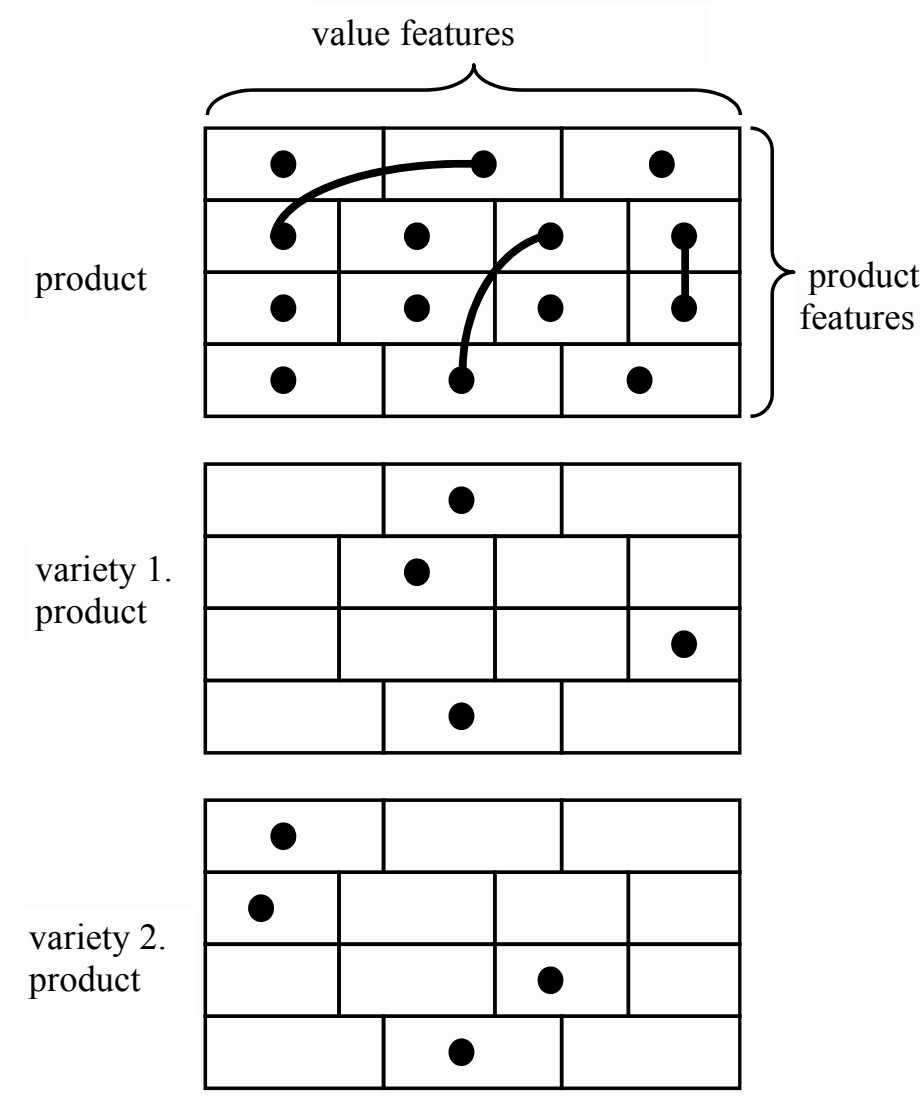

Figure 4a. An example of product and two of its varieties (source: own elaboration) 
A product ( $\mathrm{PRi}$ ) is a typical representative of all variants of a resource that can be created on a given set of attributes and their values. The product is interpreted as a generalized definition of technologically acceptable varieties. The product and the product variety are in the structure of the production system associated with the buffer attached to the machine.

The $\mathrm{j}$ variant of product PRi (designation PROi.j) is representative of a resource with predetermined characteristic values defined for the given PRi product. Some combinations of values of the characteristics are due to technological, economic or other reasons (e.g., esthetic, environmental, ethnic) are considered unacceptable; hence only predetermined product variants can be prepared. This situation is illustrated in Fig. 4a. Unacceptable pairs of values for different features are indicated in the drawing by the line joining the points.

For organizational and economic reasons (Czakon, 2011; Ficoń, 2007; Krupa, Wiśniewski 2015a, 2015b), a description of a production order may be accompanied by a priority and more specific time characteristics such as, for example, the earliest and most appropriate start and end date for a batch of orders or a production order.

Production orders are divided into cooperative $\left(\mathrm{O}^{\mathrm{C}}\right)$, internal $\left(\mathrm{O}^{\mathrm{I}}\right)$ and final $\left(\mathrm{O}^{\mathrm{F}}\right)$.

Cooperative, internal and final orders create a dynamic network of orders realized in the form of a t-network.

$\mathrm{O}^{\mathrm{C}}$ orders specify the product variants that are manufactured to be addressed in the production system supplying $\mathrm{B}^{\mathrm{S}}$ t-network buffers.

$\mathrm{O}^{\mathrm{I}}$ orders specify product variants that are made for the $\mathrm{B}^{\mathrm{T}}$ t-network buffers (as the $\mathrm{O}^{\mathrm{I}}$ orders assigned to the $\mathrm{B}^{\mathrm{T}}$ buffers).

The formal definition of any cooperation order (sign: $\mathrm{O}^{\mathrm{C}} \mathrm{i} . \mathrm{j}$ ), internal order (sign: $\mathrm{O}^{\mathrm{I}} \mathrm{i} . \mathrm{j}$ ) or final order (sign: $\mathrm{O}^{\mathrm{F}} \mathrm{i} . \mathrm{j}$ ) consists in giving:

- the index and name of the order $\left(\mathrm{O}^{\mathrm{C}} \mathrm{i} . \mathrm{j}, \mathrm{O}^{\mathrm{I}} \mathrm{i} . \mathrm{j}, \mathrm{O}^{\mathrm{F}} \mathrm{i} . \mathrm{j}\right)$,

- the type and variety of the product (PRi, PROi.j),

- the number of products of the same variety (PRON),

- the earliest moment in time at which the first product (order) will be delivered to the buffer,

- the earliest moment in time at which the last product (order) will be passed to the buffer,
- and the latest time at which the last product (order) will be sent to the buffer.

The production order is based on the product, its variety and the technology of the variety. The technology for manufacturing a given product variant clearly identifies its constituent variants (with the possibility of alternative variants). The technology for producing the variety is defined only for the non-elementary product variation (product variation calculated is taken as product orders cooperative).

Products of different types have different structures and different sets of features. Products of one kind but of different varieties have an equal set of characteristics and different values for characteristics. Products of the same variety are products of the same type - i.e., of the same structure and with the same characteristics. The product is described by:

- its product identifier $(\mathrm{Pi})$,

- the structure $\left(\mathrm{P}_{\mathrm{i}} \mathrm{S}\right)$ of the product expressed by the formula $\&-\mathrm{V}$,

- a set of product characteristics $\left(\mathrm{P}_{\mathrm{i}} \mathrm{C}\right)$,

- a repertoire (sets) of product characteristics values $\left(\mathrm{P}_{\mathrm{i}} \mathrm{C}_{\mathrm{j}} \mathrm{W}\right)$.

Product structure is a form of product interpretation using a well-chosen relationship. The product structure relationship is based on the repertoire of machine operations included in the production system expected to produce this product. The structure of the product is described by:

- the set of products $\left(\left\{\mathrm{P}_{\mathrm{i}}\right\}\right)$,

- the structure of the product $\left(<\mathrm{P}_{\mathrm{i}} \mathrm{R}>\right)$ described by the formula $\&-\mathrm{V}$ and the following signs: $\mathrm{V}$ symbolizes an alternative to the implementation of internal tasks, and \& symbolizes the connotation of the implementation of internal tasks.

The structure of the product is presented in a formal way using the $\&-V$ diagrams which describe the technology of producing individual variants of this product. The expanded product structure (RSP) is also presented in a formal way using the \&-V diagrams. In the developed product structure at the highest level is the final product, and at the lowest, there are elementary products. 
The product structure relationship is based on the repertoire of technology transformers (modeled by tnetwork transformers) integrated into the t-network, which is a simulation model of the production system and projected for product realization.

The structure of a product is expressed by the formula $\&-\mathrm{V}$ in the form:

$$
\mathrm{P}_{0}\left\{\&_{1} / \mathrm{V}_{1} \mathrm{P}_{\mathrm{i}}\left\{\&_{2} / \mathrm{V}_{2} \mathrm{P}_{\mathrm{j}}\left\{\ldots\left\{\&_{\mathrm{n}} / \mathrm{V}_{\mathrm{n}} \mathrm{P}_{\mathrm{q}}\right\} \ldots\right\}\right\}\right\}
$$

where:

$\mathrm{P}_{0}, \mathrm{P}_{\mathrm{i}}, \mathrm{P}_{\mathrm{j}}, \ldots, \mathrm{Pq}$ - are products in the field of technological operations,

$\&_{s} / V_{s}-$ means a conjunction or an alternative at level $\mathrm{s}$,

$\{\ldots\}-$ means recurrent repetition of an internal expression.

The structure of the product of technological operations marked $<*>$ and organizational operations marked $(*)$ may be expressed by the formula $\&-\mathrm{V}$ in the form:

$$
\begin{aligned}
& \mathrm{P}_{0}(*)\left\{\&_{1} / \mathrm{V}_{1} \mathrm{P}_{\mathrm{i}}=\mathrm{P}_{\mathrm{i} 0}<*>/ \mathrm{VP}_{\mathrm{i} 1}<*>\right. \\
& / \mathrm{V} \ldots<>/ \mathrm{VP}_{\mathrm{ir}} \\
& (*)\left\{\&_{2} / \mathrm{V}_{2} \mathrm{P}_{\mathrm{j}}=\mathrm{P}_{\mathrm{j} 0}<*>/ \mathrm{VP}_{\mathrm{j} 1}<*>\right. \\
& / \mathrm{V} \ldots<>/ \mathrm{VP}_{\mathrm{js}} \\
& (*)\left\{\ldots \left\{\&_{\mathrm{n}} / \mathrm{V}_{\mathrm{n}} \mathrm{P}_{\mathrm{q}}=\mathrm{P}_{\mathrm{q} 0}<*>/ \mathrm{VP}_{\mathrm{q} 1}<*>\right.\right. \\
& \left.\left.\left./ \mathrm{V} \ldots<>/ \mathrm{VP}_{\mathrm{q}\}} \ldots\right\}\right\}\right\}
\end{aligned}
$$

where:

(*) symbolizes the organizational operation that means "indication of the product variant (order) to be implemented".

The division of products into types and varieties is based on the organizational conditions (Kaleta, 2011; Korzeniowski, 2012) that characterize the production system, such as:

- the machine may perform technological operations on a specific batch of processed products; changing this assembly to another requires the machine to be disconnected from the production system and reassembled to match the feeder and receive (feed) buffers.

- machine operations may involve products of multiple varieties (for a given product type) but each processed variety of the product only belongs to the one currently being processed on the given machine.

\section{$5 \quad$ Multitasking t-network}

Multitasking is a natural feature of the t-network. To understand this, it is sufficient to interpret a single order or a group of orders as a whole, hereafter referred to as a task. We assume here that multilevel tasks can be decomposed (expansion or disintegration) into a simple task layer, and their results can be aggregated (in aggregate) in the opposite direction (from elementary products to finished products (complex resources) (Romanowska, 2011; Zawiła-Niedźwiecki, 2010, 2014).

T-network describes the structure of tasks and the order of their implementation, and refers to logistic issues in which the task is interpreted (connected) with the flow (and activity) of the products (resources) necessary for its implementation. The ability to flow timing tasks is an intrinsic feature of the t-network products - more specifically, their orders - are stored in buffers. Product transformations (orders) describe the transformers; the problem is interpreting the desired (expected) products (orders) in the buffers.

Summary multitasking interpreted in the t-network is in accordance with Fig. 4a, in respect to such planning (addressing time and the appropriate buffer) and the coordinate (priority orders' buffers variants mapping transformers in accordance with the priorities of the flow of orders to be implemented according to a specific function of the target). The way in which the objective function is "transformed" into the decomposition and the placement of task streams is transformed into orders in t-buffers is usually accomplished by scenarios.

The t-network's multitasking is based on the assumption that its structure is designed for a certain task class that uniquely identifies a subset of output buffers (final tasks) and, at the same time, the task assigned to the input buffers (cooperative/input tasks) network. Each t-network buffer specifies only one task type according to its type. There may of course be many buffers of the same type of order (processing the same type of resource).

In the buffer of a given type of task, many different variants of a given task may be executed or planned. Hence, building a multitasking t-network must precede the type of task that the network will perform. For each of the defined task types, the appropriate number 
of buffers with capacities to ensure a harmonized task execution must then be selected.

\section{Functioning and products in transformer networks}

The functioning of the t-network decides its internal functions' transformation that for each transformer describes the way in which the transformation takes orders entering and leaving the transformer. Since task orders are stored in buffers, two factors can be decisive for the transformation process:

- the availability and ordering of orders in buffers,

- and initiating job transformations (priorities) according to a set plan or strategy.

Exemplary rules for ordering order markers in buffers include LIFO, FIFO, or priorities resulting from a plan or other logistical order execution strategy.

As a result of subsequent simulations in Table $3 \mathrm{~b}$, there has been a systematical decrease in the number of orders initiated after the transformations (positions $4 \Rightarrow 8,8 \Rightarrow 6,12 \Rightarrow 3$ and $16 \Rightarrow 0$ ) and in the number of transformers available.

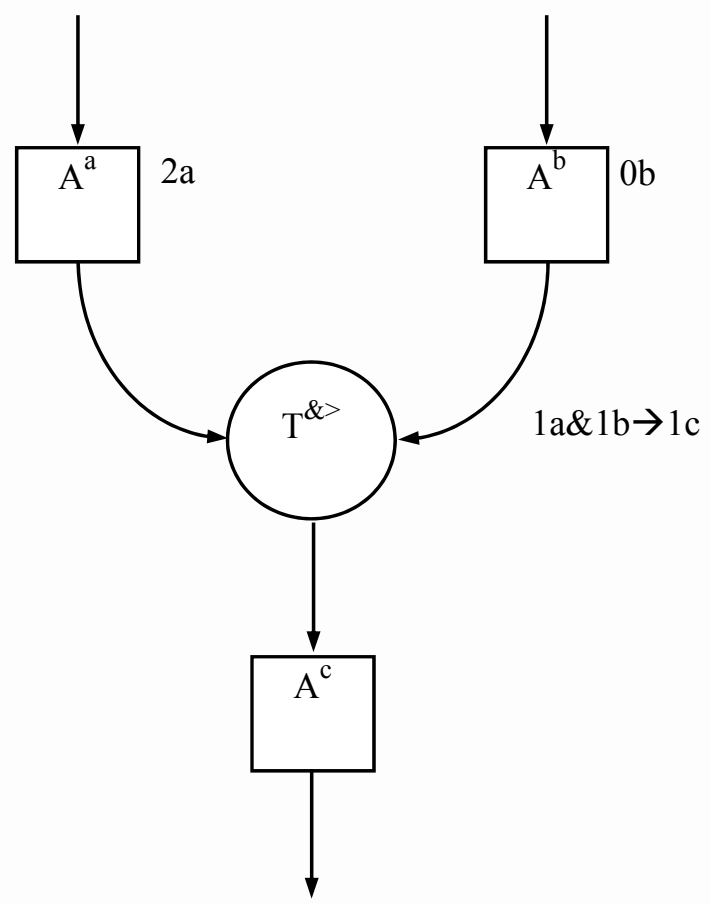

Figure 6a. The transformer $T^{\&>}$ that concenters parallelly in standby condition due to a lack of required $\mathrm{b}$ jobs in the input buffer (source: own elaboration)
The operation of the t-network can be fully described by the set of transformation functions, $\mathrm{T}$. The transformer network functions asynchronously activate the transformer at appropriate times and automatically lock up the overloaded jobs (buffers) of the buffers.

The condition that blocks the technological transformation of the converting transformers is that an alternative or parallel aggregate transformer (Fig. 6a) does not have a sufficient number of orders required for logical processing operations in the buffers, thus resulting in a single $n$-fold order.

The task of the parallel transformer $\mathrm{T}_{\mathrm{j}}^{\&>}$ is to take one input order from all buffered buffers and then convert it into one output order and simultaneously, after a certain delay $\tau_{j}$, transfer it at the only output of the $T_{j}$ $\&$ transformer to the attached buffer. This process is illustrated in Fig. 6a.

The alternative focus transformer (Fig. 6b) or parallel has enough buffers in the supply buffers to execute logical operations that result in a single $n$-fold order that does not fit in the receiving buffer.

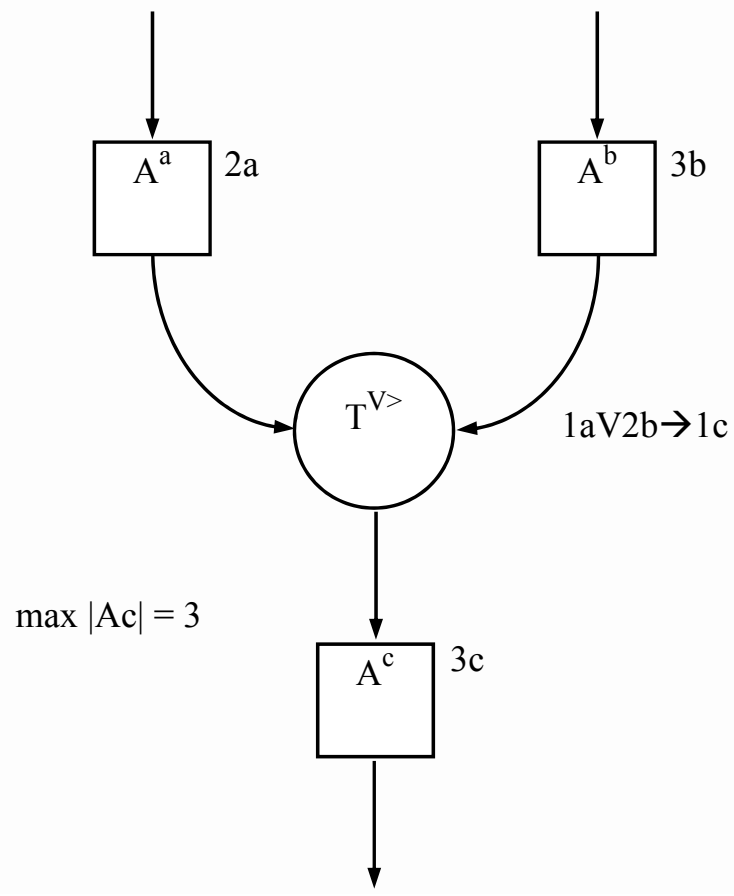

Figure $6 \mathrm{~b}$. The transformer $\mathrm{T}^{\mathrm{V}>}$ that concenters alternatively in standby condition due to a buffer overflow host (source: own elaboration) 
The purpose of the alternative transformer is to retrieve the required number of input orders from one of the connected buffers and then convert them into one output order and simultaneously, after a certain delay $\tau_{\mathrm{j}}$, transfer it to the only output of the transformer $T_{j}{ }^{\&}>$ to the connected buffer. This process is illustrated in Fig. 6b.

\section{$7 \quad$ Summary}

It is extremely important to be able to simulate tnetwork behavior when it handles streams of randomly generated job streams in its input buffers. Such a network should provide in its structure the feasibility of incoming tasks within the limits of time and costs.

If we assume that the t-network buffers have a limited capacity with respect to the number of stored job tags and at the same time the transformers execute a finite number of allowed transformations in a finite number of time units, then these limits also result in a finite number of possible t-network states - the current location of orders (products) in all buffers with the currently performed set of logical transforming functions.

It is easy to see that even in very small t-networks, the number of permissible states increases exponentially with respect to the number of buffers, their capacities, and the time and functional characteristics of the transformers. For example, for the t-network shown in Fig. $3 \mathrm{a}$, assuming that each buffer can contain no more than two orders, the number of possible states can be estimated at about 16,000 without taking into account the effects of implementing transforming functions.

An important warning regarding constructing and modeling numerous variants of the network is the accompanying analysis of correctness conducted in accordance with the axiom of correctness. These axioms should be specified a priori before the beginning of modeling.

In each case, the problem preceding the modeling and simulation of the t-network behavior is in determining the aforementioned faultless structures which are easier and more efficient than searching for errors in already constructed t-networks. In other words, the correct functioning of any transforming network, consisting of the order buffers and the processing of these logic functions, should be preceded by a definition for the axioms of the correct function; this means there is a need to develop a specific (individual) theory for the structural-functional relationships of the elements of the transforming network theory.

\section{$8 \quad$ References}

[1] Czakon, W., 2011. Zasobowa teoria firmy ograniczenia w badaniu zjawisk międzyorganizacyjnych (The Reosurce-Based Theory of Enterprise - Limitations in the Study of Interorganizational Phenomena). In: R., Krupski, ed. Rozwój szkoly zasobowej zarzadzania strategicznego (Development the Resource-Based School of Strategic Management). Wałbrzych: Wałbrzyska Wyższa Szkoła Zarządzania i Przedsiębiorczości, ISBN 978-83-60904-13-8, pp.185198.

[2] Ficoń, K., 2007. Inżynieria zarzadzania kryzysowego. Podejście systemowe (Crisis Management Engineering. System approach). Warszawa: BEL Studio.

[3] Frączkiewicz-Wronka, A., 2011. Podejście zasobowe $\mathrm{w}$ zarządzaniu organizacją publiczną perspektywa interesariuszy. In: R. Krupski, ed. Rozwój szkoty zasobowej zarzadzania strategicznego (Development the Resource-Based School of Strategic Management). Wałbrzych: Wałbrzyska Wyższa Szkoła Zarządzania i Przedsiębiorczości, ISBN 978-83-60904-13-8, pp.281310.

[4] Kaleta A., 2011. Relacje między zasobowym i pozycyjnym podejściem do zarządzania strategicznego we współczesnych przedsiębiorstwach (The Relationship between Resource and Positional Approach to Strategic Management in Modern Enterprises). In: R. Krupski, ed. Rozwój szkoły zasobowej zarzadzania strategicznego (Development the Resource-Based School of Strategic Management). Wałbrzych: Wałbrzyska Wyższa Szkoła Zarządzania i Przedsiębiorczości, ISBN 978-83-60904-13-8, pp.23-36.

[5] Korzeniowski, L.F., 2012. Podstawy nauk o bezpieczeństwie. Zarzadzanie bezpieczeństwem (The Basis of Safety Science. Safety Management). Warszawa: Difin.

[6] Krupa, T., 1990. Parallel Processing of Resources in T networks. In: Int. Conf. SYPRO'90 
Systemy Produkcyjne - Teoretyczne i Praktyczne Problemy Projektowania (Production Systems - Theoretical and Practical Design Issues). Warszawa: IOSP PW, pp.443-449.

[7] Krupa, T., 2000. Wielozadaniowa sieć transformująca (Multipurpose Transformation Network). In: R. Knosala (ed.) Komputerowo Zintegrowane Zarzadzanie (Computer Integrated Management). Warszawa: WNT, pp.326-338.

[8] Krupa, T., 2002. Kolorowana sieć Petri'ego i sieć transformująca (Colored Petri network and transforming network). In: Zeszyty Naukowe IOSP PW - Organizacja i Zarzqdzanie Przemystem (IOSP PW Science Notebooks - Organization and Management of Industry). Warszawa: OW PW, No. 15, pp.5-24.

[9] Krupa, T., 2006. Elementy organizacji. Zasoby i zadania (Organizational Elements. Resources, and Tasks). Warszawa: WNT.

[10] Krupa, T., 2010. Transforming Nets. Foundations of Management, Vol. 02, No. 1. Warsaw: Warsaw University of Technology, pp.21-40, DOI: 10.2478/v10238-012-0019-6.

[11] Krupa, T., Wiśniewski, M., 2015a. Situational Management of Critical Infrastructure Resources under Threat. Foundations of Management, Vol. 07. Warsaw: Warsaw University of Technology, pp.93-104, DOI: 10.1515/fman-2015-0028.

[12] Krupa, T., Wiśniewski, M., 2015b. Wykorzystanie wiedzy w zarządzaniu sytuacyjnym bezpieczeństwem infrastruktury krytycznej Polski (Use of Knowledge in Situational Management of Critical infrastructure Security in Poland). Logistyka (Logistics), No. 5, pp.1027-1034, CD.

[13] Maj, K., Krupa, T., 2010. The Management Method Preventing a Crisis Situation in an Electrical Energy Utility. Foundations of Management, Vol. 02, No. 2.Warsaw: Warsaw University of Technology, pp.37-50, DOI: 10.2478/v10238-012-0027-6.

[14] NPOIK - Narodowy Program Ochrony Infrastruktury Krytycznej (National Critical Infra- structure Protection Program), 2013. http://rcb.gov.pl/wp-content/uploads/NPOIKdokument-główny.pdf.

[15] Ostrowska, T., Krupa, T., 2014. Przetwarzanie zasobów w sieciach technologicznych (Processing of Resources in Technological Networks). In: Logistyka (Logistics), No. 5, Instytut Logistyki i Magazynowania (Institute of Logistics and Warehousing), pp.1189-1198 (CD).

[16] Ostrowska, T., Krupa, T., 2017. Determinants of Critical Infrastructure Resources. Foundations of Management, Vol. 9, Warsaw: Warsaw University of Technology, pp.331-346, DOI: 10.1515/fman-2017-0025.

[17] Romanowska, M., 2011. Zasobowe ograniczenia reorientacji strategicznej (Resources Restriction of Strategic Reorientation). In: R. Krupski, ed. Rozwój szkoły zasobowej zarządzania strategicznego (Development the Resource-Based School of Strategic Management). Wałbrzych: Wałbrzyska Wyższa Szkoła Zarządzania i Przedsiębiorczości, ISBN 978-83-60904-13-8, pp.3744.

[18] Wiśniewski, M., 2016. Concept of Situational Management of Safety Critical Infrastructure of State. Foundations of Management, Vol. 08, Warsaw: Warsaw University of Technology, pp.297-310, DOI: 10.1515/fman-2016-0023.

[19] Zawiła-Niedźwiecki, J., 2008. Ciagtość Działania Organizacji (Business Continuity of the Organization). Warszawa: Oficyna Wydawnicza Politechniki Warszawskiej.

[20] Zawiła-Niedźwiecki, J., 2010. Business Continuity. Foundations of Management, Vol. 2, No. 2, Warsaw: Warsaw University of Technology, pp.101-118, DOI: 10.2478/v10238-012-0031-x.

[21] Zawiła-Niedźwiecki, J., 2014. Operational risk as a problematic triad: risk - resource security business continuity. Kraków: edu-Libri, ISBN: 978-83-63804-42-8. 